\begin{abstract}
Iranica
Abstracta Iranica Revue bibliographique pour le domaine irano-aryen

Volume 32-33 | 2013

Comptes rendus des publications de 2009-2010

\section{Pardis Minucheher. Sur-i Israfil in Exile: Modern Definitions of Monarchy}

Denis Hermann

\title{
OpenEdition
}

1 Journals

Édition électronique

URL : http://journals.openedition.org/abstractairanica/40773

DOI : 10.4000/abstractairanica.40773

ISSN : 1961-960X

Éditeur :

CNRS (UMR 7528 Mondes iraniens et indiens), Éditions de l'IFRI

\section{Édition imprimée}

Date de publication : 1 décembre 2013

ISSN : 0240-8910

\section{Référence électronique}

Denis Hermann, «Pardis Minucheher. Sur-i Israfil in Exile: Modern Definitions of Monarchy », Abstracta Iranica [En ligne], Volume 32-33 | 2013, document 291, mis en ligne le 01 juillet 2016, consulté le 27 septembre 2020. URL : http://journals.openedition.org/abstractairanica/40773 ; DOI : https://doi.org/ 10.4000 /abstractairanica.40773

Ce document a été généré automatiquement le 27 septembre 2020.

Tous droits réservés 


\title{
Pardis Minucheher. Sur-i Israfil in Exile: Modern Definitions of Monarchy
}

\author{
Denis Hermann
}

\section{RÉFÉRENCE}

Pardis Minucheher. « Sur-i Israfil in Exile: Modern Definitions of Monarchy ». Iranian

Studies, 42/3, 2009, p. 389-409.

1 L'A. est déjà revenue sur la presse en exil au cours du mouvement constitutionnaliste (voir c.r. $n^{\circ}$ 216, Abs. Ir., 28, 2005). Cet article traite du rôle de pro-constitutionnalistes exilés à Yverdon, en Suisse, après le bombardement du parlement le 23 juin 1908. Ces réfugiés continuèrent depuis l'Europe à imprimer le journal Sur-i Israfil. Cette dernière publication maintenant bien connue joua un rôle prépondérant dans la critique du souverain Muhammad 'Alī Šāh (m. 1925) et dans la réflexion sur l'institution monarchique. Un grand nombre d'articles revenaient sur les concepts de monarchie de droit divin, la légitimité monarchique en islam ou encore les attributs mythiques du souverain. A ce titre, 'Alī Akbar DeH̆odā (m. 1959) militait particulièrement dans les colonnes du journal en faveur de l'abdication du souverain qajar. D'autres auteurs assimilèrent l'attribution de qualités divines au Šāh à de l'associationnisme (širk). 


\section{AUTEURS}

\section{DENIS HERMANN}

CNRS, Mondes iranien et indien, Paris 